\title{
IMPROVING STUDENTS LISTENING SKILL BY USING AUDIO VISUAL MEDIA
}

\author{
Mei Hardiah \\ University of Bengkulu \\ mhardiah@unib.ac.id
}

\begin{abstract}
Teaching Listening skills to the students who learn English as a foreign language is a challenge for the teacher. This classroom action research (CAR) designed to improve the listening ability of students by using audio-visual media. The subject of this research are students of English, University of Bengkulu Diploma Program who take the course Listening For Lecture. This study was conducted in two cycles of progress namely; planning, observation, action and reflection. Moreover, collaborative learning methods are also applied to stimulate student activeness in the classroom. The results showed that the use of audio visual media is able to improve the results of listening course. In addition, the students also Become more motivated and enthusiastic during the lecture which can be seen in the group discussion stage that implement colaborative learning. Generally it can be concluded that audio visual media can improve the focus and concentration of students in listening courses. In addition to the use of audio visual media, the selection of the topic material also influence the results of students listening comprehension.
\end{abstract}

Key words: Students ability, Listening Comprehension, Audio Visual Media

\section{Introduction}

In language teaching, four language skills which include reading, writing, listening and speaking are absolutely taught to students. Reading and listening skills are grouped as receptive skills or input while writing and speaking skills are productive skills or output. The four skills must be taught to language learners integratedly. Students will be able to write if they are able to read well and the ability to speak will be good if they have good listening skills.

Teaching English as a foreign language in Indonesia naturally requires the mastery of these four skills to their students. Authentic material and context are needed in teaching foreign languages. Therefore the teaching of the four language skills in teaching English should use the material and the English context as well. However, there are many obstacles faced by English educators to be able to teach these four skills proportionally. 
Of the four skills mentioned above, teaching listening skills is a skill that tends to be ignored in the teaching and learning process. This is due to several reasons including lack of facilities, lack of teacher competence and lack of motivation from students themselves. In teaching listening skills, adequate facilities such as a conducive room, free noise, and adequate media such as audio recorders and videos are needed. Authentic materials must also be used because of this listening skill students learn many things such as suprasegmental segments of language, namely intonation and emphasis. The role of the teacher is also very important in the teaching of this listening skill, the teacher must be able to play a role as a guide and designer of learning that is in accordance with the abilities of their students. Teachers are also required to be able to use appropriate strategies in teaching listening skills. Besides that the low motivation of students since they feel listening skills are difficult to be mastered. While listening, students are required to actively respond to and interpret the information being listened. In other words listening is an active activity that involves not only good listening ability but also the ability to sort and interpret information obtained from this activity (Ulum: 2015).

Teaching listening skills in teaching English is not an easy thing. In listening activities, students are required to be able to elaborate information that is heard with other information that has already been known and interpret its meaning by integrating what is heard with existing data in the brain (Helgesen, 2003). According to Tyagi (2013) the listening process includes four stages namely listening, understanding, remembering, evaluating and responding. Given the complexity of the process in listening skills, the right method needs to be applied so that students are able to explore listening skills maximally.

Based on the writer experience during teaching the Listening course, English D3 students tend to have inadequate listening skills. This is due to several factors, especially the factors of learning media and a less conducive learning environment. Listening to the class during this time only uses audio media. The problem is that students have difficulty concentrating when audio is played. Besides that, the laboratory room is feasible for listening activities because it is not soundproofed so that noise interference from outside is still heard. In addition, the arrangement of the seats is no different from ordinary lecture rooms so that students easily interact with their own friends during the learning activities, which of course will interfere the concentration of other students. As a result of the evaluation of learning in this case the middle and end examinations of the semester, students' grades are not satisfaction. 
In language teaching, listening and reading is a skill that is receptive, meaning that this skill is the target language input for language learners. Language learners are expected to get the target language input from these two skills. Gass and Selinker (2001) state that even though the input from listening and reading alone is not enough in language acquisition, input is needed for second language learning (foreign languages).

Underwood (1989) simply defines listening as an activity that focuses on understanding the meaning of what is being heard. Listening skills in learning English require students to be able to identify accents, know how to pronounce vocabulary, grammar rules, and understand vocabulary meaning. Therefore listening skill is not a simple skill because it requires focus, concentration and the ability to elaborate information so as to obtain food. In other words, listening is an active process that involves the mind.

To help students improve listening skills, choosing the right strategy is needed. The use of authentic teaching materials and providing relevant tasks is very necessary in teaching listening skills. The use of media such as news broadcasts, films, songs and audio visual media will greatly help students improve listening skills. Of course the strategy used must be adjusted to the ability of students. The stages in learning listening skills include the stages of prelistening, while-listening, and post listening. Each can be done using a specific method.

Audio Visual is a media that simultaneously presents audio (sound) and visual images. By using this medium, the two senses are activated at the same time, namely the ears and eyes. The use of this media is expected to be able to attract students to listen more focused and be able to synchronize information heard with the help of visualization of images so that a better understanding will be obtained. Some audio visual media that can be used in learning listening skills are flashcard, audioslide, films, lectures, broadcast news. For students with intermediate levels film media, scientific lectures and news can be used.

Collaborative learning is very necessary in teaching listening skills. Collaborative learning in learning listening skills not only allows students to listen to each other's opinions, but also finds out how an idea is formed, how to convey their views, and clarify the interpretations they make through collaborative activities. This process allows students to explore, develop, monitor, and determine their thoughts that are delivered collaboratively with other students. Collaborative activity in the teaching of listening skills is very appropriate to be applied in the pre-(before) and post-(after) listening phases. 


\section{Research methods}

The design of this research is classroom action research. In general, classroom action research is research conducted by teachers based on the problems encountered in the teaching and learning process carried out. The purpose of this classroom action research is to find a solution to the problems of the existing teaching and learning process so as to produce a method of improvement to improve the quality of learning. Classroom action research consists of several cycles, each of which consists of the stages of preparation, action, observation and reflection. Cycles can be stopped when the desired results are obtained as stated by Kemmis and Mc Taggart (1998) that classroom action research consists of a continuous cycle until the researcher achieves satisfactory results and feels confident to stop research activities.

This study was designed in two cycles by using audio visual media to improve listening skills of English students in the Listening for Lecture class. The stages in this study, in each cycle include planning, action, observation, and reflection.

\section{Planning}

At this stage everything that is needed in the teaching and learning process that will be carried out includes what, who, where, and how. The planning stage can be described as follows; Determine the research schedule, design learning activities (lesson plan), prepare teaching materials, and prepare observation sheets and student worksheets (tests)

\section{Action}

The researcher as well as the teacher will take the following actions; Students are given clue about the material to be delivered, students are divided into small groups and given the task to predict the contents of the lecture to be listened to (pre-listening task), students are given the opportunity to listen to listening material through audio visual media 2 times and each each student is given a worksheet about the material they will hear (While-listening task), the students are divided into small groups to brainstorm on perceptions and interpretations of what they have listened to through the audio visual media (Post listening task), in the final stages of students individually instructed to make a summary based on the results of interpretation and brainstorming in small groups

\section{Observation}


At this stage the researcher observes the activeness of students in group discussions and also the concentration and focus of students during listening activities with audio visual media applied.

\section{Reflection}

In the final stage of this cycle the researcher collects student work in the form of worksheets and summary. Then analyze the observation checklist and video recorder data to conclude the activities that occur in cycle 1 . Then the researcher will discuss the improvement of planning based on the results of the analysis of observation checklist and student achievement in cycle 1 and design activities in cycle 2 when the indicators of success have not been achieved.

\section{3 . DISCUSSION}

This classroom action research was carried out in 2 cycles on 2 face-to-face meetings in class. This study aims to see the effect of the use of audio visual media on the ability to listen to students in the Listening for lecture course. The audio visual media used is in the form of short scientific lectures on certain topics downloaded from youtube media .

In general, the results of the study showed a positive influence from the use of audio visual media on student listening comprehension results . On two cycles of using audio-visual media carried proven to increase focus and concentration of students which always be a problem when it used only in the form of audio. With the use of audio visual media, students' focus and concentration increased because video media was able to provide focus so that students concentrate more on the while listening stage . Besides that the collaborative learning method is applied at the post listening stage, is able to motivate students to improve their understanding in listening comprehension . it is alsi found that the selection of topic/material also affect students' listening comprehension results.

This research was carried out in 2 cycles with 1 meeting for each cycles due to time constraints. This research was conducted in the Listening For Lecture class of 3rd semester 
students of the English D3 Study Program. Each cycle consists of planning, action, observation and reflection stages. Based on the writer experience and observations, listening ability of students, especially students of Diploma III English, is still low. In addition to the lack of variety in media used, student motivation is also weak. During this time listening teaching only uses audio media that requires concentration and focus of students while supporting facilities such as the location and atmosphere of the classroom are less supportive. Often audio used when listening classes must compete with sound from outside the room. Therefore, research on the use of audio visual media in this listening class is conducted. This study applies 2 cycles which are described as follows:

Cycle 1 consists of the stages of planning, action, observation and reflection. Planning. At the planning stage, everything that is needed in the teaching and learning process is prepared. At this stage learning activities are designed (Lesson Plan), sorting and selecting audio visual media that will be used by downloading from the youtube site. After obtaining a video in the form of videos that are considered appropriate, the video lecture with the topic Introduction to Linguistics is approximately 6 minutes. The next step is to prepare the student worksheet (worksheet students).

Action Stage . This stage is the implementation of the planning that is using audio visual media (video ) in the Listening for Lecture course. This stage consists of 3 parts, namely pre-listening, while-listening, and Post-Listening . After greeting and checking attendance, researchers who acted as instructors asked students questions about "What Is Linguistics". Some students responded by answering " the study about language" . Students are able to answer well because in the previous semester students have already received an Introduction to Linguistics course . Furthermore, the discussion continued about the division in linguistics and general explanations such as multi-disciplinary linguistic studies. After brainstorming 
about Linguistics, student worksheets were distributed to each student. Next, enter part I, where the video lecture on Introduction to Linguistics is played. In the first video round, students are asked to listen only without making notes or answering questions in the worksheet. This is done so that students can capture the main idea of the material presented. After seeing and listening for the first time students are given questions about what will be discussed in the lecture. At this stage almost $50 \%$ of students are able to provide a good response. Before the video is played for the second time, the lecturer discusses the questions in the worksheet with the aim of the students knowing the direction of the questions that must be answered in the worksheet. Then the video is played back and students are allowed to make notes or answer questions in the worksheet. This activity takes place by playing 2 videos so that the entire video is played 3 times. Then enter the post-listening section where students are asked to discuss in pairs with friends who sit next to them ( in pairs ). The time given for discussion is 15 minutes. Then each pair wrote the answers on the board and then discussed them together.

Observation Phase . During the action phase, the researcher who acts as a teacher observes each student's actions. In this first cycle several things can be concluded as observations, among others; (1) students reponded enthusiastically when brainstorming about listening material will be discussed. This is because students already have sufficient knowledge about the topic to be discussed (Background knowledge). (2) In the action stage when the video is played all students' attention is directed at the video being played. At this stage students are seen to focus and concentrate fully on what is being heard. (3) In general discussion students look quite active (4) Students are enthusiastic to write the answers on the board

Reflection Phase . After the action is taken, students are asked to collect worksheets. Next asking students' responses to the use of audio visual media in listening learning . All students said they understood better, were more focused and concentrated so they could better 
understand the contents of the " lecture ". Based on students' answers and enthusiasm it can be concluded that audio visual media is very helpful for students in understanding scientific lectures better.

Cycle 2 this study was conducted on Thursday, October 12, 2017 at 10.00-12.00 WIB in the Language Lab Building Room of FKIP learning in the Department of Language and Art Education. This room is wider and more comfortable than the previous room used in cycle 1. Like cycle 1 , this cycle 2 also consists of 4 stages, namely planning, action, observation and reflection.

Planning stage. Referring to the results of cycle 1 which is quite satisfying, at this stage the selected video has a longer duration with a more specific topic, Psycholinguistics. This topic was chosen because it is still related to language learning. The next step is to prepare student worksheets ( student worksheets ).

Action Stage . This stage is the implementation of the planning that is using audio visual media (video ) in the Listening for Lecture course. This stage consists of 3 parts, namely pre-listening, while-listening, and Post-Listening. After greeting and checking attendance, researchers who acted as instructors asked students questions about Psycholinguistics. Some students respond by giving the correct answer. Furthermore, the discussion continued about the acquisition of language in children. After brainstorming about Psycholinguistics, student worksheets were distributed to each student. Then begin the while-listening section, played the video lecture about psycholinguistics . In the first video round, students are asked to listen only without making notes or answering questions in the worksheet. This is done so that students can capture the main idea of the material presented. After seeing and listening for the first time students are given questions about what will be discussed in the lecture. Unlike the sikus 1 , at this stage only a few students were able to give a good response. Before the video 
is played for the second time, the lecturer discusses the questions in the worksheet with the aim of the students knowing the direction of the questions that must be answered in the worksheet. Then the video is played again and students are allowed to take notes or answer questions in the worksheet. This activity takes place by playing the video 3 times so that the entire video is played 4 times at the request of the student. Next the post-listening section. Unlike what was done in cycle 1 , in this section students were asked to have groups of 3 . Because of the adequate space, students can discuss more freely. The time given for discussion is 15 minutes. Then each group wrote the answers on the board and then discussed them together.

Observation Phase . During the action phase, the researcher who acts as a teacher observes each student's actions. In this second cycle several things can be concluded as observations, among others; Students were respod enthusiastically when brainstorming about will be discussed. However, students find it difficult to answer when they were being asked about language acquisition. In the action stage when the video is played all the students' attention is directed to the video being played. At this stage students are seen to focus and concentrate fully when the first video is played but some students start to do other activities when the second, third and fourth videos are played. In general discussion students look quite active . Students are eager and enthusiastic to write answers on the board

Reflection phase . After the action is taken, students are asked to collect worksheets. Next asking students' responses to the use of audio visual media in listening learning . Almost all students answered they were having a hard time understanding the content of the lecture because they were less familiar with the terms used. This is because students do not get psycholinguistics material in depth because they are only taught briefly in an introduction to linguistics course, in other words students do not have adequate background knowledge. Others complained about the duration they considered long. Based on the answers of students 
in this second cycle, it can be concluded that the duration and background knowledge are very influential on students' ability to understand listening comprehension well.

\section{CONCLUSION}

From the results of classroom action research conducted on students of Diploma 3 English by using audio-visual media to improve the ability of students listening can be concluded that in general the audio-visual media is very effective to help students understand the listening comprehension. In addition, the use of this media is able to increase the focus and concentration of students during listening activities. Cooperative learning techniques also help students to be more confident to solve problems in learning. In addition, background knowledge is also very influence towards the understanding of students in listening.

\section{BIBLIOGRAPHY}

Anwar, Stefany Melinda., Increasing Speaking \& Listening in English Language through Audiovisual Method of SDK Santo James Makassar. Article on the Faculty of Cultural Sciences Hasanuddin University Postgraduate program.

Field, J. (2002). The Change Face of Listening. In: Jack.C. Richard \& Willy A. Renandya (Eds.), Methodology in Language Teaching. Cambridge University Press, 246

Gass, SM \& Selinker, L. (2001). Second Language Acquisition: An Introductory Course (2nd.ed) Pui Mahwah, New Jersey, Lawrence Erlbaum Associates.

Ulum, Omer Gokhan., (2015). Listening: The Ignored Skill in EFL Context. International Journal of Humanities ocial Sciences and Education. Vol. 2 Issue. 5 pp. 257-270

Seo.K (2001). The effect of visuals on listening comprehension, A Study of Japanesse Learner is listening strategies. International Journal of Listening. Vol.15, 57-81 
Sutriyani, Nur Idha., (2015). The Use of Audiovisual Media to Improve the Ability of Primary School Student Listening. UPI anthology. Vol. Edissi Number 1-8

Wen-Sheng, Zhang. (2007) Teach More Strategies in EFL College Listening Classroom. USChina Education Review, Vol. 4.No.3 